\title{
PENGARUH AKTUALISASI DIRI DAN DUKUNGAN SOSIAL TERHADAP KETAKUTAN AKAN SUKSES PADA WANITA KARIR
}

\author{
EFFECT OF SELF-ACTUALIZATION AND SOCIAL SUPPORT TO FEAR WILL SUCCESS \\ IN CAREER WOMEN
}

LINGGA PRAMANA PUTRA

Fakultas Psikologi, Universitas 17 Agustus 1945

Email : Lingga.pramana91@gmail.com

\begin{abstract}
Abstrak: Penelitian ini bertujuan untuk membuktikan secara empiris apakah terdapat pengaruh aktualisasi diri dan dukungan sosial terhadap ketakutan akan sukses. Terdapat tiga variabel yang akan diselidiki dalam penelitian ini , yaitu : 1) Aktualisasi Diri terhadap Ketakutan Akan Sukses ; 2) Dukungan Sosial terhadap Ketakutan Akan Sukses ; 3) Aktualisasi Diri dan Dukungan Sosial terhadap Ketakutan Akan Sukses. Penelitian dikenakan kepada 60 wanita karir. Pengambilan sampel dalam penelitian ini menggunakan teknik purposive sampling. Teknik analisis data yang digunakan dalam penelitian ini adalah analisis regresi berganda. Hasil penelitian ini menunjukkan ada pengaruh Aktualisasi Diri (X1) terhadap Ketakutan Akan Sukses (Y) dengan nilai $p<0,05$ dan nilai $p=0,007$. Ada pengaruh Dukungan Sosial (X2) terhadap Ketakutan Akan Sukses (Y) dengan nilai $p<0,05$ dan nilai $\mathrm{p}=0,002$. Kemudian terdapat pengaruh Aktualisasi diri (X1) dan Dukungan Sosial (X2) terhadap Ketakutan Akan Sukses $(Y)$ dengan nilai $p<0,05$ dan nilai $p=0,000, F=10,046$.
\end{abstract}

Kata Kunci : Aktualisasi Diri, Dukungan Sosial, Ketakutan Akan Sukses

Abstract: This study aims to determine whether there is influence of self-actualization and social support to the fear of success. So there are three effects will be investigated in this study, namely: 1) self-actualization of the fear of success. 2) social support to the fear of success. 3) self-actualization and social support to the fear of success. This research applied to female employees in the office of the border areas of the city development agency Samarinda. Research applied to career woman who worked in the office of the border area development agency in the city of Samarinda. sampling in this study using purposive sampling technique. Data analysis techniques used in this study is multiple regression analysis. The results of this study showed no effect of self-actualization (X1) against the fear of success $(Y)$ with grades $p<0,05$ dan nilai $p=0,007$. There is the influence of social support $(X 2)$ on the fear of success $(Y)$ with value $p<0,05$ and values $p=0,002$. Then there is the effect of self-actualization (X1) and social support (X2) against the fear of success $(Y)$ with $p<0,05$ and $p=$ 0,000, F 10,046.

Keyword : Self-Actualization, Social Support, Fear of Success 


\section{PENDAHULUAN}

Perubahan pandangan tentang kemampuan wanita membuat wanita bangkit memperjuangkan haknya. Wanita telah banyak merambah kehidupan publik, yang selama ini didominasi pria. Saat ini telah banyak wanita memasuki dunia kerja. Ada berbagai alasan yang mendorong mereka untuk bekerja dan meninggalkan rumah antara lain untuk mandiri secara ekonomi tidak tergantung pada suami, menambah penghasilan keluarga, mengisi waktu luang serta untuk mengembangkan prestasi atau keahlian-keahlian yang dimiliki (Ananda, 2013:41)

Partisipasi wanita saat ini bukan sekedar menuntut persamaan hak tetapi juga menyatakan fungsinya mempunyai arti bagi pembangunan dalam masyarakat Indonesia. Partisipasi wanita menyangkut peran tradisi dan transisi. Peran tradisi atau domestik mencangkup peran wanita sebagai istri, ibu dan pengelola rumah tangga. Sementara peran transisi meliputi pengertian wanita sebagai tenaga kerja, anggota masyarakat dan manusia pembangunan. Peran transisi wanita sebagai tenaga kerja turut aktif dalam kegiatan ekonomis (mencari nafkah) di berbagai kegiatan sesuai dengan keterampilan dan pendidikan yang dimiliki serta lapangan pekerjaan yang tersedia (Rahmadita, 2013:59).

Dalam berita resmi tahun 2007, BPS mencatat partisipasi perempuan dalam lapangan kerja meningkat signifikan. Selama februari 2006-februari 2007, jumlah pekerja perempuan bertambah 2,12 juta orang, terbesar di sektor pertanian dan perdagangan, sedangkan jumlah pekerja laki-laki hanya bertambah 287 ribu orang.

Peningkatan jumlah pekerja perempuan yang bekerja di sektor publik sebagaimana data di atas menunjukkan bahwa perjuangan kaum perempuan menuntut persamaan hak atas laki-laki mulai membuahkan hasil. Kini wanita tidak lagi bekerja untuk membantu suami memenuhi kebutuhan keluarga, tetapi juga demi memenuhi tuntutan aktualisasi diri yang ada di dalam dirinya. Wanita diberi kesempatan seluas-luasnya untuk mengenyam pendidikan setinggi-tingginya. Semakin tingginya pendidikan, semakin besar keinginan wanita untuk bekerja. Dengan demikian makin banyak pula wanita yang terjun ke dalam dunia kerja.

\section{METODE PENELITIAN}

\section{A. Tipe Penelitian}

Dalam bab ini akan diuraikan mengenai metode yang digunakan dalam penelitian. Metode penelitian menurut Sugiyono (2011:3) pada dasarnya merupakan cara mendapatkan data dengan tujuan dan kegunaan tertentu.

\section{B. Subyek Penelitian}

\section{Populasi}

Menurut Sugiyono (2012) populasi adalah wilayah generalisasi yang terdiri atas obyek atau subyek yang mempunyai kualitas dan karakteristik tertentu yang di tetapkan oleh peneliti untuk dipelajari dan kemudian ditarik kesimpulannya.

Dalam penelitian ini populasinya adalah semua wanita yang memiliki peran ganda yaitu yang sudah menikah, bekerja untuk mengembangkan kemampuannya, dan tinggal di Kota Samarinda

\section{Sampel}

Menurut Sugiyono (2012:120) sampel adalah bagian dari jumlah dan karakteristik yang dimiliki oleh populasi tersebut. Bila populasi besar, dan peneliti tidak mungkin mempelajari semua yang ada pada populasi misalnya karena keterbatasan dana, tenaga dan waktu maka peneliti dapat menggunakan sampel yang di ambil dari populasi itu. Dalam penelitian ini sampel yang digunakan Purposive Sampling.

Adapun ciri-ciri subyek dalam penelitian ini adalah :

a. Wanita karir

Alasan peneliti mengambil subyek ini karena para pegawai wanita memiliki kesempatan untuk mengembangkan karirnya. Selain itu juga memiliki visi untuk kesetaraan dan keadilan gender pada semua aspek kehidupan.

b. Wanita yang sudah menikah 
Alasan peneliti memilih subyek yang sudah menikah karena wanita yang sudah menikah memiliki peran ganda. Disatu sisi wanita harus bertanggung jawab mengurus pekerjaannya dikantor dan disisi lain mereka harus mengurus urusan rumah tangga seperti mengurus suami atau anak.

c. Usia 20-50 tahun

Usia 20-50 tahun masih memberikan kesempatan untuk memenuhi kebutuhan aktualisasi diri seorang wanita karir.

d. Pendidikan minimal SMA

Dengan pendidikan minimal SMA seorang wanita dapat mengawali suatu kesempatan bekerja guna mendapatkan kehidupan yang layak.

\section{Analisis Data}

Untuk melihat pengaruh aktualisasi diri dan dukungan sosial terhadap ketakutan akan sukses maka penulis menggunakan analisis regresi linier berganda. Penggunaan metode ini untuk memprediksi hubungan diantara lebih dari dua variabel, yaitu penelitian ini variabel Y (ketakutan akan sukses) terhadap variabel X1 (aktualisasi diri) dan $\mathrm{X} 2$ (dukungan sosial). Pengujian hipotesis ini menggunakan teknik analisis regresi linier berganda dengan program SPSS (Statistic Of Package Science) 23 for windows.

\section{A. Pembahasan}

1. Pengaruh Aktualisasi Diri terhadap Ketakutan Akan Sukses pada wanita karir di Badan Pengelolaan Kawasan Perbatasan Pedalaman Dan Daerah Tertinggal.

Berdasarkan hasil Pengujian menunjukkan ada pengaruh signfikan antara aktualisasi diri (X1) dengan ketakutan akan sukses (Y) karena nilai $\mathrm{p}<0,05$ dan nilai $\mathrm{p}$ adalah 0,007 menunjukkan pengaruh nilai korelasi negatif yang kuat. Artinya ada pengaruh korelasi yang negatif. Semakin tinggi aktualisasi diri maka ketakutan akan sukses akan semakin rendah. Adapun nilai $\mathrm{R}$ square adalah 0,119 dalam hal ini berarti 11,9\% ketakutan akan sukses dipengaruhi oleh aktualisasi diri.

Hal ini sejalan dengan penelitian yang dilakukan oleh Fakhrurrozzi (2012). dalam penelitian tersebut terdapat hubungan yang signifikan antara motivasi berprestasi dengan ketakutan akan sukses. Hubungan yang ditujukan bersifat negatif, artinya semakin tinggi motivasi berprestasi subyek maka semakin rendah ketakutan akan sukses dan semakin rendah motivasi berprestasi subjek semakin tinggi ketakutan akan sukses.

2. Pengaruh Aktualisasi Diri dan Dukungan Sosial terhadap Ketakutan Akan Sukses pada wanita karir di Kantor Badan Pengelolaan Kawasan Perbatasan Pedalaman Dan Daerah Tertinggal Kota Samarinda

Berdasarkan hasil pengujian menunjukkan ada pengaruh signfikan antara Aktualisasi Diri (X1) terhadapKetakutan Akan Sukses (Y) nilai $\mathrm{p}<0,05$ dan nilai $\mathrm{p}$ adalah 0,006 menunjukkan pengaruh nilai korelasi negatif yang kuat. Dan dukungan sosial (X2) terhadap ketakutan akan sukses (Y) nilai $\mathrm{p}<0,05$ dan nilai $\mathrm{p}$ adalah 0,002 . Sedangkan $\mathrm{R}$ square adalah 0,261. Hal ini berarti 26,1\% ketakutan Akan Sukses dipengaruhi oleh variabel aktualisasi diri dan dukungan sosial pada wanita karir. Hasil penelitian ini sejalan dengan penelitian yang dilakukan oleh Yusnita (2010) bahwa ada dua hal yang dialami pegawai wanita ketika mereka harus menempuh pengembangan karir, yaitu ketakutan akan sukses. Bagi pegawai wanita pengembangan karir akan memunculkan perasaan ketakutan akan sukses terlebih dahulu yang selanjutnya berdampak pada munculnya konflik pekerjaan dan kehidupan rumah tangga. 


\section{HASIL DAN PEMBAHASAN}

1. Pengaruh Aktualisasi Diri terhadap Ketakutan Akan Sukses pada wanita karir di Badan Pengelolaan Kawasan Perbatasan Pedalaman Dan Daerah Tertinggal. Berdasarkan hasil Pengujian menunjukkan ada pengaruh signfikan antara aktualisasi diri (X1) dengan ketakutan akan sukses (Y) karena nilai $\mathrm{p}$ $<0,05$ dan nilai $\mathrm{p}$ adalah 0,007 menunjukkan pengaruh nilai korelasi negatif yang kuat. Artinya ada pengaruh korelasi yang negatif. Semakin tinggi aktualisasi diri maka ketakutan akan sukses akan semakin rendah. Adapun nilai $\mathrm{R}$ square adalah 0,119 dalam hal ini berarti $11,9 \%$ ketakutan akan sukses dipengaruhi oleh aktualisasi diri. Hal ini sejalan dengan penelitian yang dilakukan oleh Fakhrurrozzi (2012). dalam penelitian tersebut terdapat hubungan yang signifikan antara motivasi berprestasi dengan ketakutan akan sukses. Hubungan yang ditujukan bersifat negatif, artinya semakin tinggi motivasi berprestasi subyek maka semakin rendah ketakutan akan sukses dan semakin rendah motivasi berprestasi subjek semakin tinggi ketakutan akan sukses.

2. Pengaruh Aktualisasi Diri dan Dukungan Sosial terhadap Ketakutan Akan Sukses pada wanita karir di Kantor Badan Pengelolaan Kawasan Perbatasan Pedalaman Dan Daerah Tertinggal Kota Samarinda. Berdasarkan hasil pengujian menunjukkan ada pengaruh signfikan antara Aktualisasi Diri (X1) terhadapKetakutan Akan Sukses (Y) nilai $p<0,05$ dan nilai $p$ adalah 0,006 menunjukkan pengaruh nilai korelasi negatif yang kuat. Dan dukungan sosial (X2) terhadap ketakutan akan sukses (Y) nilai $\mathrm{p}<0,05$ dan nilai $\mathrm{p}$ adalah 0,002 . Sedangkan R square adalah 0,261. Hal ini berarti 26,1 \% ketakutan Akan Sukses dipengaruhi oleh variabel aktualisasi diri dan dukungan sosial pada wanita karir. Hasil penelitian ini sejalan dengan penelitian yang dilakukan oleh Yusnita (2010) bahwa ada dua hal yang dialami pegawai wanita ketika mereka harus menempuh pengembangan karir, yaitu ketakutan akan sukses. Bagi pegawai wanita pengembangan karir akan memunculkan perasaan ketakutan akan sukses terlebih dahulu yang selanjutnya berdampak pada munculnya konflik pekerjaan dan kehidupan rumah tangga.

\section{KESIMPULAN}

Penelitian ini meneliti tentang aktualisasi diri, dukungan sosial dan ketakutan akan sukses pada wanita karir. Baik itu mengenai pengaruh aktualisasi diri terhadap ketakutan akan sukses, dukungan sosial terhadap ketakutan akan sukses, maupun pengaruh aktualisasi diri dan dukungan sosial terhadap ketakutan akan sukses. Penelitian ini dilakukan di Kantor Badan Pengelolaan Kawasan Perbatasan Pedalaman Dan Daerah Tertinggal Kota Samarinda Perbatasan Daerah. Penelitian ini menggunakan metode kuantitatif korelasional untuk mencari pengaruh aktualisasi diri, dukungan sosial, dan ketakutan akan sukses.

Hasil uji hipotesis diperoleh sebagai berikut :

1. Hasil Pengujian menunjukkan ada pengaruh signfikan antara aktualisasi Diri (X1) dengan ketakutan akan sukses (Y) karena nilai $\mathrm{p}<0,05$ dan nilai $\mathrm{p}$ adalah 0,007 menunjukkan pengaruh nilai korelasi negatif yang kuat. Adapun nilai $\mathrm{R}$ square adalah 0,119 dalam hal ini berarti $11,9 \%$ artinya semakin tinggi aktualisasi diri maka semakin rendah ketakutan akan sukses.

2. Hasil Pengujian menunjukkan ada pengaruh signifikan antara dukungan sosial (X2) dengan ketakutan akan sukses (Y) karena nilai $\mathrm{p}<0,05$ dan nilai $\mathrm{p}$ adalah 0,002 menunjukkan pengaruh nilai korelasi negatif yang kuat. Adapun nilai $\mathrm{R}$ square adalah 0,155 dalam hal ini berarti $15,5 \%$ ketakutan akan sukses dipengaruhi oleh dukungan sosial. Artinya semakin tinggi dukungan sosial maka semakin rendah ketakutan akan sukses.

3. Hasil pengujian menunjukkan bahwa ada pengaruh aktualisasi diri (X1) dan dukungan sosial (X2) terhadap ketakutan akan sukses (Y). Pada ANOVA, nilai 
10,046 dengan 0,000 Dikarenakan $\mathrm{p}<$ 0,05 , maka terdapat pengaruh aktualisasi diri (X1) dan dukungan sosial (X2) terhadap ketakutan akan sukses (Y). Artinya ada pengaruh aktualisasi diri dan dukungan sosial terhadap ketakutan akan sukses. Semakin tinggi aktualisasi diri dan dukungan sosial maka ketakutan akan sukses semakin rendah.

\section{DAFTAR PUSTAKA}

Adibah, P. \& Fakhrurozzi, M. (2012). Hubungan Antara Motivasi Berprestasi dengan Fear Of Success pada Wanita Bekerja Dewasa Muda. Universitas Gunadarma Yogjakarta. Jurnal Psikologi.

Allen. (2004). Rahasia Kesuksesan Hidup. Yogyakarta. PENERBIT ORCHID

Aminah, S. \& Juniarto, G. (2013). Pengaruh Kebutuhan akan Pretasi, Kebutuhan Afiliasi, Kebutuhan Dominasi dan Kebutuhan Otonomi terhadap Kesuksesan Entrepreneur Wanita di Kota Semarang. Junal Ilmiah Dinamika Ekonomi dan Bisnis. Vol.01, No. 02, 48-59.

Alwisol. (2011). Psikologi Kepribadian. Malang. UMM Press.

Ananda, M. A. (2013). Self Esteem Antara Ibu Rumah Tangga Yang Bekerja Dengan Yang Tidak Bekerja. Jurnal Online Psikologi, Vol. 01, No.01. 40-54.

Ayugrahani, N. (2007). Ketakutan akan Sukses Pada Ibu Bekerja Ditinjau Dari

Orientasi Peran Jenis Tradisional Dan Situasi Kompetensi Kerja. Universitas Katolik Soegijapranata Semarang [Skripsi].

Baihaqi, M (2011). Psikologi Pertumbuhan. Bandung. PT REMAJA ROSDAKARYA.

Budiati, A. C. (2012). Aktualisasi Diri Perempuan dalam Sistem Budaya
Jawa. Jurnal Sosiologi. Vol. 29, No.01. 13-22.

Ciptoningrum, P. (2009). Hubungan Peran Ganda dengan Pengembangan Karir Wanita. Institut Pertanian Bogor. [Skripsi].

Darmasaputra, A. \& Satiningsih. (2013). Hubungan Antara Dukungan Sosial Teman Kerja dengan Kinerja Pegawai di Kantor Kecamatan Jombang. Universitas Negeri Surabaya. Vol. 01, No. 02, 1-5.

Halida, O. (2013). Karier, Uang, dan Keluarga:Dilema Wanita Pekerja. Universitas Diponegoro Semarang. [Skripsi].

Hasan, S. A. (2014). Hubungan Antara Dukungan Sosial Teman Sebaya dengan Penyesuaian Diri Siswa Tunarungu di Sekolah Inklusi. Jurnal Psikologi Pendidikan dan Perkembangan. Vol. 03, No. 02, 128135.

Hadi, Sutrisno. 2004. Analisis Butir untuk Instrument. Yogyakarta: ANDI OFFSET

Indrawan, R. \& Yaniawati, P. (2014). Metodologi Penelitian. Bandung. PT REFIKA ADITAMA.

Indrawati, E. S. \& Saputri, A. M. W. (2011). Hubungan Antara Dukungan Sosial Dengan Depresi Pada Lanjut Usia Yang Tinggal Di Panti Wreda Wening Wardoyo Jawa Tengah. Jurnal Psikologi Undip. Vol. 09, No. 01, 6572

Martono, N. (2011). Metode Penelitian Kuantitatif. Jakarta. Pt Raja Grafindo Persada.

Mujiasih, E., Prihatsanti, U., Nurtjahjanti, H., Prasetyo, A., R., Ratnaningsih, I., Z., (2007). Hubungan Antara Efikasi Diri dan Persepsi Terhadap Pengembangan Karir dengan Work 
Family Conflict Pada Polwan di Polrestabes Semarang. eJurnal Psikologi. Universitas Diponegoro. Semarang

Nety. (2012). Meraih Sukses dan Rumah Tangga Bagi Wanita karir. Yogyakarta. PUSTAKA PELAJAR.

Putri, T. D. (2007). Kebutuhan Aktualisasi Diri pada Remaja Penyandang Tunanetra yang Bersekolah di Sekolah umum ditinjau dari Kematangan Emosi dan Self Disclosure. Universitas Muhammadiyah Surakarta. Naskah Publikasi.

Rahmadita, I. (2013). Hubungan Antara Konflik Peran Ganda dan Dukungan sosial Pasangan dengan Motivasi Kerja pada Karyawati Rumah Sakit Abdul Rivai-Berau. eJournal Psikologi. Vol 01, No. 01, 58-68

Realyta, S. (2007). Fear Of Success Wanita Bekerja Pada Etnis Melayu. Universitas Sumatera Utara Medan. [Skripsi]

Rini, H. P. (2013). Self Efficacy dengan Kecemasan dalam Menghadapi Ujian Nasional. Jurnal online psikologi. Vol. 01, No. 01, 30-39

Sari, R. M. (2012). Pengaruh Situasi Kompetensi Kerja Terhadap Fear Of Success Pada Pegawai Wanita. Journal of Social and Industrial Psychology, Vol. 01, No. 01. Thn 2012.

Sahrah, A. (2011). Pengaruh Atribusi Kesuksesan Terhadap Ketakutan untuk Sukses Pada Wanita Karir. Pyscho Idea, Tahun 9, No. 02, 2012.

Sugiyono. (2012). Metode Penelitian Kombinasi (Mixed Methods). Bandung. ALFABETA, cv.

Triananda, K. (2015, 06 Maret). 2030, CEO Perempuan Akan Makin Banyak. Gaya Hidup [on-line]. Diakses pada tanggal 15 April 2015 dari http://www.beritasatu.com/gayahidup/254857-2030-ceo-perempuanakan-makin-banyak.html

Winarsunu, T. (2009). Statistik dalam penelitan psikologi pendidikan. Malang. UMM Press.

Yusnita, R. T. (2010). Pengaruh Pengembangan Karir Terhadap Konflik Pekerjaan-Keluarga dan Ketakutan akan Kesuksesan Pada Wanita Serta Dampaknya Pada Prestasi Kerja. Survey pada Pemerintah Kota Tasikmalaya Tahun 2010. 